\title{
Antibacterial Activity of Various Plants Extracts Against Antibiotic-resistant Aeromonas hydrophila
}

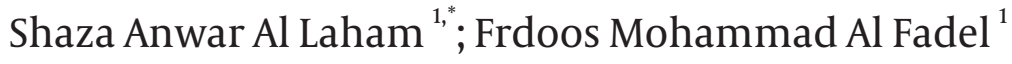 \\ ${ }^{1}$ Department of Pharmacology and Toxicology, Faculty of Pharmacy, Damascus University, Damascus, Syria \\ ${ }^{*}$ Corresponding author: Shaza Anwar Al Laham, Department of Pharmacology and Toxicology, Faculty of Pharmacy, Damascus University, Damascus, Syria. Tel: +96-30113136591, E- \\ mail: Lahamshaza@gmail.com-
}

Received: March 31, 2013; Revised: June 1, 2013; Accepted: June 25, 2013

\begin{abstract}
Background: Aeromonas hydrophila cause one of the most important diseases in fishes and lead to economic losses, and may be contaminated human beings.

Objectives: The current research aimed to investigate the anti-bacterial activity shown by the extracts prepared from different parts of Olea europea, Myrtus communis, Thymus vulgaris, Rosmarinuis officinalis, and Achillea falcata that grow in Syria against A. hydrophila that causes the most dangerous bacterial diseases in fish.

Materials and Methods: The study was performed in four stages: First of all, the presence of A. hydrophila was investigated in 450 Samples of Cyprinus Carpio fish using blood agar, Trypticase soya agar, and Analytical Profile Index (API20E). Secondly, the plants extract was obtained using water, absolute alcohol, then ether using Soxhlet extraction apparatus and rotary vacuum evaporator. Thirdly, the antibacterial activity of some antibiotics on these bacteria was evaluated by disk diffusion method. Finally, the antibacterial effect of the extracts was determined by disk diffusion method.

Results: The studied antibiotics showed no antibacterial activity against these bacteria, except amikacin which had an acceptable effectiveness. However, the ethanol extracts of the studied plants revealed different antibacterial effects against A. hydrophila which showed antibiotic resistant. T. vulgaris extract had the strongest effect, whereas O. europea extract had the weakest activity. The water and ether petroleum extracts had no antibacterial activities.

Conclusions: Ethanol extracts of the studied plants had different antibacterial effects against antibiotic-resistant A. hydrophila. T. vulgaris had the highest activity, R. officinalis had the second, and M. communis and A. falcate were in the third place, while the O. europea had the weakest antibacterial activity.
\end{abstract}

Keywords:Antibacterial Properties, Disk Diffusion Test, Plants; Aeromonas hydrophila

\section{Background}

Aeromonas hydrophila is among the most common bacteria in freshwater habitats throughout the world (1). It causes a variety of zoonotic diseases in both human and fish (2). A. hydrophila is associated with cellulitis, an infection that causes inflammation in the skin tissue $(2,3)$. Aeromonas species are most commonly causative agents of gastroenteritis (4), an inflammation of respiratory tract, and diarrhea accompanied with high temperature (5). Sepsis is a fatal complication of Aeromonas infections. Feasible virulence factors of Aeromonas species include fimbrial and afimbrial adhesion molecules, hemolysins, enterotoxins, lipases and proteases (4).

A. hydrophila is hard to remove, because it is resistant to chlorine and refrigeration or cold temperatures (6). In addition, it is very toxic to many organisms because of its structure. When it enters the body of fish, amphibians, or humans, it travels via the bloodstream to the first available organs. It produces cytotoxic enterotoxin (Act) which is one of the major virulence factors. Its toxin is produced and secreted by the cell from a type II secretion system. The toxin binds to high-affinity receptors and undergoes oligomerization to form a heptameric pore-forming complex which allows passage of small molecules in the plasma membrane, resulting in permeabilization of the cell, cell death, and eventually tissue destruction. A. hydrophila is also known as an opportunistic pathogenic bacterium that is they only infect immunocompromised hosts (7).

The volatile oils of black pepper, clove, glycine max (1.) merr and perry, geranium, nutmeg, oregano, Thymus vulgaris (8), and acetone and hexane extracts of Pterocarpus angolensis, Syzygium cordatum, and Zornia milneana showed inhibitory activity against all Aeromonas isolates (9). Also Guava and Neem extracts showed higher antimicrobial activity against Gram-negative bacteria such as A. hydrophila (10).

Researchers try to develop new broad-spectrum antibiotics against bacteria, because the extended use of antibiotics has led to drug resistance. It directed the authors to make new medical plants which are a rich source of many compounds such as polyphenols. Polyphenols are a group of highly hydroxylated phenolic compounds

Copyright (C 2014,Ahvaz Jundishapur University of Medical Sciences; Published by Kowsar Corp. This is an open-access article distributed under the terms of the Creative Commons Attribution License, which permits unrestricted use, distribution, and reproduction in any medium, provided the original work is properly cited. 
which exist in the extractive fraction of several plant components. Polyphenols are proved to have bactericide activities against a huge number of pathogenic bacteria. Polyphenols in plants include flavanols, flavonols, flavanones, flavones, anthocyanins, proanthocyanidins (tannins), hydroxystilbenes, and aurones (11). Flavonoids are now the subject of medical research. They have been reported to possess many useful properties, including anti-inflammatory, oestrogenic, enzyme inhibition, and antimicrobial effects (12).

Therefore, from the flavonoid family the chosen plants were the leaves of Olea europea Linn from the Oleaceae, Myrtus communis Linn back to Liliaceae, Thymus vulgaris from the Laminaceae, and Rosmarinuis officinalis Linn (Rosemary. L) and the flowers of Achillea falcata Linn back to the Asteraceae.

R. officinalis, contains a variety of compounds including carnosol, carnosic acid, rosmanol, 7-methyl-epirosmanol, isorosmanol, rosmadial, caffeic acid, 1,8 cineol, camphor and $\alpha$-pinene, which have in vitro antimicrobial and antioxidant activities. 1,8 cineol, $\alpha$-pinene and camphor have been identified as the most active antimicrobial components (13).

The 0 . europea Linn from Oleaceae, is an evergreen longlasting fruit tree, and is rooted in the Mediterranean region (14). Olive leaves are a good source of several antioxidants including oleuropeoside compounds such as oleuropein and verbascoside, and flavonoid compounds such as luteolin, luteolin-7-glucoside, apigenin-7-glucoside, diosmetin, diosmetin-7-glucoside, rutin and catechin, and simple phenolic compounds such as tyrosol, hydroxytyrosol, vanillin, vanillic acid and caffeic acid (13).

T. vulgaris L. (thyme), locally known as "Zaatar", a member of the family Lamiaceae, is widely used in traditional medicine for its expectorant, antitussive, antibroncholitic, antispasmodic, anthelmintic, carminative and diuretic effects. The aromatic and medicinal properties of the genus Thymus have made it one of the most popular plants all over the world. Thymus species are commonly used as herbal tea, flavoring agents and medicinal plants. The published results reveal that major volatile constituents obtained from the aerial parts of the plant are geranial, linalool, $\gamma$-terpineol, carvacrol, thymol and trans-thujan4-ol/terpinen-4-ol. Recent studies have shown that Thymus species have strong antibacterial, antifungal, antiviral, anti-parasitic, spasmolytic and antioxidant activities (15).

Indigenous uses of Achillea species are diuretic, emmenagog agents, wound healing, curing stomachache, diarrhea and antispasmodic, and are also used in cosmetics. Recent studies reported that Achillea species had constituents such as flavonoids (aglycones and glycosides), sesquiterpene lactones and essential oils, the major constituents are 1, 8-cineole, camphor, piperitone and ascaridole (16). M. communis grows throughout the Mediterranean area and has been used for medicine, food and spice since the ancient times. In folk medicine, the fruit of the plant is used to treat various infectious diseases, including di- arrhea and dysentery, whereas the leaves are used as antiseptic and anti-inflammatory agents, like mouthwash, they are also used to treat candidiasis, heal wounds, and in the therapy of urinary tract diseases. The leaves contain tannins, flavonoids such as quercetin, catechin and myricetin derivatives and volatile oils (17).

\section{Objectives}

The current research aimed to investigate the anti-bacterial activity of the examined plant extracts prepared from different parts of O. europea, M. communis, T. vulgaris, R. officinalis, and A. falcata that grow in Syria against Aeromonas hydrophila that causes the most dangerous bacterial diseases in fish.

\section{Materials and Methods}

\subsection{Collection of Plant Material}

O. europea, M. communis, and T.vulgaris leaves, and A. falcata flowers were collected in the early morning hours from June to August 2010 in Damascus rural areas, while the $R$. officinalis leaves were purchased from Damascus market and the identity was confirmed by Damauscs University. The plants were washed with cold distilled water, and then dried under hot air at a temperature not exceeding $60^{\circ} \mathrm{C}$ in the shadow. The samples were crushed properly by metal mortar until a fine homogeneous powder was obtained, kept in paper bags under free humidity conditions (1).

\subsection{Preparing Plant Extracts}

Plant extracts were prepared separately by a continuous extraction apparatus (Soxhlet apparatus), the method already described by Wang (6) for preparing plant extracts by organic solvents as follows: $50 \mathrm{~g}$ of plant powder was placed inside the thimble-holder of Soxhlet apparatus in addition to $500 \mathrm{~mL}$ of each organic solvent (rate 1:10 w: v). Three different polar solvents have been selected to extract the components of the plants, water, absolute ethanol, then light petroleum. Extraction continued for four hours, until the solvent that came out of the thimble became colorless. Then to concentrate the extracts, the ethanol and petroleum ether extracts were dried using rotary vacuum evaporator at a temperature not exceeding $40^{\circ} \mathrm{C}$, while the aqueous extract was dried using freeze dryer. The thick layer of the bottom was stored in sterile bottles at $4^{\circ} \mathrm{C}$ for further experiments. All the extracts were filter-sterilized using $0.45 \mu \mathrm{m}$ membrane filters (Whatman, UK) (1).

\subsection{Sampling Method}

Four hundred and fifty Samples from the intestines of the infected Cyprinus carpio fish with dermal ulceration received at the Central Laboratory of Veterinary from Althoura branch of fish of Raqqa province were investigated for the presence of A. hydrophila. The samples were 
preserved at 2 to $4^{\circ} \mathrm{C}$ and transported to the laboratory immediately. Glassware and culturing tools were sterilized. The samples were placed in sterile tubes, fitted with a strap closure, and the card number included name of the sample, place, and date of collection.

\subsection{Method of Culturing Pathological Samples}

Media cultures were Prepared, then each sample was placed in a tube containing $5 \mathrm{~mL}$ of nutrient broth and incubated for 24 hours at $37^{\circ} \mathrm{C}(1,18,19)$.

\subsection{Identification Method of the Bacteria}

The bacteria were identified morphologically and biochemically. The API20E system was also used to support the identification process. A. hydrophila were isolated after the following steps: Microscopic examination was conducted, then the bacteria were cultured on blood agar and trypticase soya agar (TSA) (HiMedia, India), according to Cipriano method (1) where the bacteria from the nutrient broth was cultured, then incubated for 20 to 24 hours at 35 to $37^{\circ} \mathrm{C}(20,21)$.

\subsubsection{Analytical Profile Index Technique (API 20E)}

This technique was performed according to the manufacturer's instructions (Bio Merieux, France). Oxidase, catalase, and indole tests were also conducted. Twenty three differentials Bergey's Manual of Systematic Bacteriology were performed by API 20E system (Analytical Profile Index, manufactured by Bio Merieux, France) as follows: a. Investigate the effectiveness of enzymes: 2 . nitrophenyl- $\beta$ D-galactopyranoside, arginine dihydrolase, oxidase. b. Decarboxylation interactions of amino acids: L-lysine, L-omithine; c. Deaminase interaction of the amino acid: L-tryptophan; d. Fermentation reactions of the following sugars: D-glucose, D-mannitol, Inositol, D-sorbitol, L-rhamnose, D-sucrose, D-melibiose, amygdaline arabinose; e. Production reactions: indole, asitoen; f. Reactions produce gases: hydrogen sulphide, nitrogen, nitrogen oxide; g. Study the interactions of Recipes: gelatin diluted, citrate use, hydrolysis of urea (urease).

\subsection{Antimicrobial Susceptibility Tests}

The antimicrobial susceptibility testing was done on Muller-Hinton agar by disc diffusion method (Kirby-Bauer disk diffusion susceptibility test protocol). The A. hydrophila isolates (178 samples) were individually tested against 18 antibiotics. The results were determined using the disk diffusion method (Becton Dickinson, Microbiology Systems, MD, USA) as described in the National Committee For Clinical Laboratory Standards (NCCLS2000). The tested antibiotics and concentration ranges were as follows: amikacin $(30 \mu \mathrm{g})$, ampicillin (10 $\mu \mathrm{g})$, cephalexin $(30 \mu \mathrm{g})$, cephalothin $(30 \mu \mathrm{g})$, doxycycline $(30 \mu \mathrm{g})$, cefadroxil $(30 \mu \mathrm{g})$, ciprofloxacin $(5 \mu \mathrm{g})$, clindamycin $(2 \mu \mathrm{g})$, chloramphenicol (30 $\mu \mathrm{g})$, erythromycin $(15 \mu \mathrm{g})$, gentamicin $(10 \mu \mathrm{g})$, norfloxacin $(10 \mu \mathrm{g})$, oxytetracycline $(30 \mu \mathrm{g})$, pefloxacin $(5 \mu \mathrm{g})$, oxacillin
$(1 \mu \mathrm{g})$, enrofloxacin $(5 \mu \mathrm{g})$, tetracycline $(30 \mu \mathrm{g})$ and amoxicillin $(25 \mu \mathrm{g})$. The resistance breakpoints were the same as the ones defined by the National Committee for Clinical Laboratory Standards (NCCLS, 2000) for Gram-negative bacteria (20).

\subsection{Bacterial Growth Inhibition Test of Plant Ex- tracts by the Disk Diffusion Method}

Five microliters of plants extracts $66 \mathrm{mg} / \mathrm{mL}$ (the disk concentration was $0.33 \mathrm{mg} /$ tablet) diluted in ethanol, water, and petroleum ether were impregnated into 6 $\mathrm{mm}$ sterile filter paper disks (22). All extracts were filtersterilized using $0.45 \mu \mathrm{m}$ membrane filters (Whatman Co. UK). Control disks were also prepared with absolute ethanol, water, and petroleum ether. After culturing bacteria on Mueller-Hinton agar, the disks were placed on the same plates and incubated for 17 hours at $37^{\circ} \mathrm{C}$. The diameters of the inhibition zones were measured in millimeters, and compared with those of the control and standard susceptibility disks.

\section{Results}

\subsection{Identification of the Bacteria}

Bacterial samples were identified using the tests mentioned in Table 1 and the results were compared to Cipriano and Illanchezian (2).

\begin{tabular}{lc}
\hline \multicolumn{2}{l}{ Table 1. Results of the Microbiology Laboratory Tests } \\
\hline Test & Test Result \\
\hline Microscopic examination & Gram-negative bacilli, motile (2) \\
Blood agar & $\beta$-hemolysis \\
Tryptone soya agar (TSA) & yellow pigments \\
\hline
\end{tabular}

\subsubsection{The results of biochemical tests}

The results of the biochemical tests were oxidase positive (2), catalase positive (21), and indol positive (17). The results of Analytical Profile Index technique (API20E) are displayed in Table 2 .

Table 2. Results of the Biochemical Tests based on (API20E) Technique

\begin{tabular}{lc}
\hline Test & Test Result \\
\hline Citrate & + \\
lysine decarboxylase & + \\
Ornithine decarboxylase & - \\
\hline Urease & - \\
Phenylalanine (TDA) & - \\
Nitrate production & + \\
Hydrogen sulphide $\left(\mathbf{H}_{\mathbf{2}} \mathbf{S}\right)$ & + \\
production & \\
Glucose fermentation & + \\
Lactose fermentation & - \\
Arabinose fermentation & + \\
sorbitol fermentation & - \\
\hline
\end{tabular}


4.2. Antibiotic Susceptibility Results Against A. hydrophila

A. hydrophila, a species from genus Aeromonase, were found resistant to the studied antibiotics, except for amikacin. The diameter of inhibition zones were measured, based on NCCLS 2000 criteria (20), and the standard leaflet of antibiotic discs provided by the manufacturer and the result was $23 \pm 1.2 \mathrm{~mm}$. The number of infected samples and the rate of sensitive and resistant isolates of A. hydrophila (178 samples) against the examined antibiotics is shown in Tables 3,4, respectively.

\subsection{Antibacterial Activity of Plant Extracts Against A. hydrophila.}

The ethanol extracts showed the antibacterial activity, on the contrary, the water and ether petroleum extracts had no antibacterial effects (no inhibition zone was seen). Table 5 is shown the results obtained from the antibacterial effects of the various examined extracts, in comparison with those of the control disks, through measuring the diameter of inhibition zone of antibiotic-resistant $A$. hydrophila isolates.

Table 3. Number of Infected Samples

\begin{tabular}{lc}
\hline & No. of Infected Samples (\%) \\
\hline $\begin{array}{l}\text { samples infected with } \\
\text { Aeromonas spp }\end{array}$ & $330(73.33)$ \\
$\begin{array}{l}\text { samples infected with } \\
\text { A.hydrophila }\end{array}$ & $178(39.55)$ \\
\hline
\end{tabular}

\begin{tabular}{|c|c|c|c|}
\hline Antibiotics & $\begin{array}{l}\text { Diameters Zones of Inhibi- } \\
\text { tion, } \mathbf{m m}\end{array}$ & Antimicrobial Susceptibility Results & Sensitive Bacteria,\% \\
\hline $\mathbf{T}$ & $6-8$ & resistant & 98 \\
\hline $\mathbf{A X}$ & $6-9$ & resistant & 99 \\
\hline $\mathbf{O X}$ & 7-10 & resistant & 97 \\
\hline CER & $6-8$ & resistant & 99 \\
\hline PEF & $7-9$ & resistant & 96.7 \\
\hline AK & $21-24$ & sensitive & 98 \\
\hline TE & $5-7$ & resistant & 97.11 \\
\hline CIP & $7-10$ & resistant & 89.77 \\
\hline NOR & $5-8$ & resistant & 95.98 \\
\hline $\mathbf{C N}$ & $6-8$ & resistant & 94.55 \\
\hline C & $6-8$ & resistant & 97.45 \\
\hline ENR & $7-9$ & resistant & 96.87 \\
\hline DO & $6-9$ & resistant & 97.08 \\
\hline CL & $6-9$ & resistant & 94.45 \\
\hline KF & $5-7$ & resistant & 95.86 \\
\hline DA & $7-9$ & resistant & 88.59 \\
\hline $\mathbf{A M}$ & $6-8$ & resistant & 91.61 \\
\hline $\mathbf{E}$ & $5-9$ & resistant & 98.75 \\
\hline
\end{tabular}

\begin{tabular}{lcc}
\hline Table 5. Antibacterial Activity of Examined Plant extracts Against A. hydrophila & \\
\hline Plant & Inhibition Zones of Plant Ethanol Extracts, $\mathbf{~ m m ~}$ & Sensitive Bacteria, \% \\
\hline Control/ $\mathbf{5}$ m & 0 & 0 \\
Olea europea leaves & $10-13$ & 69.12 \\
Myrtus communis leaves & $13-15$ & 96.89 \\
Thymus vulgaris leaves & $30-33$ & 97.76 \\
Rosemery leaves & $24-27$ & 98 \\
Achillea falcata flowers & $12-15$ & 97.08 \\
\hline
\end{tabular}




\section{Discussion}

In the current study, Aeromonas isolates were observed in 330 (73.33\%) of the infected fishes. Out of 450 fish samples, 178 (39.55\%) A. hydrophila isolates were obtained that is. similar to Citarasu et al. study with $80 \%$ Aeromonas spp., and 35\% A. hydrophila (23). Recently, the development of multi-resistant bacteria against different antibiotics has increased. As observed in the current study (Table 4), there was resistance against all antibiotics, except amikacin, whose inhibition zone was 21 to $24 \mathrm{~mm}$. The obtained results comply with those of Andrea Belem-Costa et al. study, who showed resistance of A. hydrophila against amoxicillin, ampicillin, and oxacillin (24). However, other studies have shown the resistance of A. hydrophila to enrofloxacin and/or ciprofloxacin (25), and also amikacin, tobramycin, and cephalosporins (26), which were not observed in the current study.

Resistance to antibiotics led the authors to develop alternative antimicrobial medicines to treat infectious diseases. So they used different Plant extracts derived from five plants. In the current study, the ethanol extracts of the five plants exhibited disparate antibacterial activities, while no effect for water, and petroleum ether extracts was observed. The diameter of inhibition zone was 30 to $33 \mathrm{~mm}$. Fabio`s study showed the greater antibacterial activity of thyme volatile oil than the ethanol extract of thyme leaves against $A$. hydrophila. The growth inhibition zone of the ethanol extract of rosemary was 24 to 27 $\mathrm{mm}$, whereas the volatile oil of rosemary had no effect on A. hydrophila (27). Moreno et al. reported that rosemary is a rich source for phenolic compounds with high antimicrobial activity against both Gram-positive and Gramnegative bacteria. They attributed the high antimicrobial activity of carnosic acid and carnosol. Carnosic acid and rosmarinic acid may be the main bioactive antimicrobial compounds which exist in rosemary extracts (28).

Essential oils derived from thymus are found to possess significant antifungal, insecticidal, and antimicrobial effects. These properties greatly depend on the chemicals attributed to their contents at phenolic compounds (thymol and carvacrol) (29). P-cymene (precursor of carvacrol) swells bacterial cell membranes to a greater extent than carvacrol does. By this mechanism p-cymene probably enables carvacrol to be more easily transported into the cell, so that a synergistic effect is achieved when the both are used together (30).

M. communis, and A.falcata had the same impact, 13 to15 $\mathrm{mm}$ growth inhibition zone diameters. Authors believe that this is the first study on the antibacterial effect of these Plant extracts on A. hydrophila. It is often reported that Gram-negative bacteria are more resistant to the Plant -based extracts and essential oils (31), since the hydrophilic cell wall structure of Gram-negative bacteria is constituted essentially of a lipo-polysaccharide (LPS) that blocks the penetration of hydrophobic oil and avoids the accumulation of essential oils in the target cell membrane (32). This is the reason that Gram-positive bacteria were found to be more sensitive to the extracts of $M$. communis than Gram-negative ones (33) and the essential oil of $A$. falcata shows inhibitory effects mainly against Gram-positive bacteria (34). M. communis leaves contain different polyphenolic classes, as flavonols and galloyl derivatives, and their antimicrobial mode of action is related to the presence of phenolic compounds. Most of the studies on the mechanism of phenolic compounds have focused on their effects on cellular membranes. They have been observed not only attacking cell walls and cell membranes, affecting their permeability and releasing intracellular constituents, but also interfering with membrane functions such as electron transport, and enzyme effect or nutrient uptake. Thus, active phenolic compounds might have several targets which could lead to the inhibition of bacteria growth (33). Moreover, $M$. comlone A\&B are considered as two new acylphloraglucinols identified in the leaves and fruits of M. communis and have shown a significant antimicrobial effect against bacteria. The inhibitory effect may be due to presence of tannin through producing hydrogen bonds with proteins, which converted its structure and led to block the protein synthesis, and tannins were considered as a phenolic compounds of plants with anti-oxidative effects (35).

Alishahi et al. revealed that the ethanol extract of $O$. europea has a little effect against this type of bacteria (10 to $12 \mathrm{~mm}$ ) (36) which confirmed the results of the current study. Oleuropein has shown to have strong antimicrobial activity against both Gram-negative and Gram-positive bacteria, as well as Mycoplasma species. Phenolic structures similar to those of oleuropein seem to have antibacterial activities through damaging the bacterial membrane and/ or disrupting cell peptidoglycans (37). However, the exact mechanism of the antimicrobial effect of oleuropein is not completely confirmed yet, although some authors have proposed that it is due to the presence of the orthodiphenolic system (catechol). Omar SH proposed that the glycoside group changes the ability to penetrate the cell membrane and get at the target site. Effective interference with the production procedures of certain amino acids necessary for the growth of specific microorganisms has been also suggested. Another proposed mechanism is the direct stimulation of phagocytosis as a response of the immune system to microbes of all types (38). Finally, plants were arranged according to their activity against $A$. hydrophila and it was found that thyme had the highest effect, rosemary had the second place, myrtus and Achilles were in the third while the olive was in the last place and had the lowest activity. Thyme showed more antibacterial activity against the examined bacteria than the strongest antibiotic amikacin; in a way that bacterial growth zone was 30 to $33 \mathrm{~mm}$, and was 21 to $24 \mathrm{~mm}$ for the thyme and amikacin, respectively.

\section{Conclusions}

The examined plant ethanol extracts showed different 
antibacterial activities against antibiotic-resistant $A$. hydrophila, while plant water and ether petroleum extracts had no antibacterial activities.

\section{Acknowledgements}

The authors are sincerely grateful to the Central Laboratory of Veterinary in Damascus for their kind assistant, and hard effort, and a special thanks to Prof. Dr. Anwar Al-Khatib from Damascus University.

\section{Authors' Contributions}

Study concept and design: Fardoos; Analysis and interpretation of data: Fardoos, and Shaza; Drafting of the manuscript: Fardoos, and Shaza; Critical revision of the manuscript for important intellectual content: Shaza; Statistical analysis: Shaza.

\section{References}

1. Cipriano RC. Aeromonas Hydrophila and motile Aeromonad Septicemias of Fish. Fish Disease Leaflet 68. .: united states department of the interior fish and wildlife service division of fishery research Washington, D. C .; 2001.

2. Seshadri R, Joseph SW, Chopra AK, Sha J, Shaw J, Graf J, et al. Genome sequence of Aeromonas hydrophila ATCC 7966T: jack of all trades. J Bacteriol. 2006;188(23):8272-82.

3. Swann LD, White MR. Diagnosis and treatment of "Aeromonas Hydrophila" infection of fish. Fact Sheet As-461 Diseases.Illinois: Aquaculture Extension Indiana Sea Grant Program Purdue University; 1914 .

4. Kobayashi H. Structural and Functional Analysis of the Serine Protease from Aeromonas sobria. Yakugaku Zasshi. 2011;131(12):1781-6.

5. Bravo L, Morier L, Castaneda N, Ramirez M, Silva M, CastroEscarpulli G. Aeromonas: an emerging pathogen associated with extraintestinal infection in Cuba. Rev Cubana Med Trop. 2003;55(3):208-9.

6. Wang L, Weller CL. Recent advances in extraction of nutraceuticals from plants. Trends Food Sci Tech. 2006;17(6):300-12.

7. Albert MJ, Ansaruzzaman M, Talukder KA, Chopra AK, Kuhn I, Rahman M, et al. Prevalence of enterotoxin genes in Aeromonas spp. isolated from children with diarrhea, healthy controls, and the environment.J Clin Microbiol. 2000;38(10):3785-90.

8. Dorman HJD, Deans SG. Antimicrobial agents from plants: antibacterial activity of plant volatile oils. J Appl Microbiol. 2000;88(2):308-16.

9. Obi CL, Ramalivhana J, Samie A, Igumbor EO. Prevalence, pathogenesis, antibiotic susceptibility profiles, and in-vitro activity of selected medicinal plants against Aeromonas isolates from stool samples of patients in the Venda region of South Africa.J Health Popul Nutr. 2007;25(4):428-35.

10. Mahfuzul Hoque MD, Bari ML, Inatsu Y, Juneja VK, Kawamoto S Antibacterial activity of guava (Psidium guajava L.) and Neem (Azadirachta indica A. Juss.) extracts against foodborne pathogens and spoilage bacteria. Foodborne Pathog Dis. 2007;4(4):4818 .

11. Dicko MH, Karou D, Simpore J, Traore AS. Antioxidant and antibacterial activities of polyphenols from ethnomedicinal plants of Burkina Faso. Afr J Biotechnol. 2005;4(8):823-8.

12. Cushnie TPT, Lamb AJ. Antimicrobial activity of flavonoids. Int J Antimicrob Ag. 2005;26(5):343-56.

13. Govaris A, Botsoglou E, Moulas A, Botsoglou N. Effect of dietary olive leaves and rosemary on microbial growth and lipid oxidation of turkey breast during refrigerated storage. S Afr J Anim Sci. 2010;40(2).

14. Belaj A, Satovic Z, Rallo L, Trujillo I. Genetic diversity and relationships in olive ( Olea europaea L.) germplasm collections as determined by randomly amplified polymorphic DNA. Theor Appl
Genet. 2002;105(4):638-44.

15. melouane B, Amhamdi H, Wathelet JP, Ankit M, Khedid K, El Bachiri A. Chemical Composition and Antimicrobial Effect of Essential Oil of Thyme (Thymus vulgaris) from Eastern Morocco. Int J Agric Biol. 2009;11(2):205-8.

16. Toncer O, Basbag S, Karaman S, Diraz E, Basbag M. Chemical com position of the essential oils of some Achillea species growing wild in Turkey. Int J Agric Biol. 2010;12(4):527-30.

17. Asif HM, Akram M, Uddin SH, Hasan ZUI, Sami A, Iqbal A, et al Myrtus communis Linn. (Pharmacological effect). J Med Plants Res. 2011;5(26):6257-9.

18. Merino S, Camprubi S, Tomas JM. Effect of growth temperature on outer membrane components and virulence of Aeromonas hydrophila strains of serotype 0:34. Infect Immun 1992;60(10):4343-9.

19. Jayavignesh V, Sendesh Kannan K, Bhat AD. Biochemical characterization and cytotoxicity of the Aeromonas Hydrophila isolated from Catfish. Arch Appl Sci Res. 2011:3(3):85-93.

20. National Committee for Clinical Laboratory Standards.. Perfor mance Standards for antimicrobial disk Susceptibility test approved standard.Wayne, PA: NCCLs; 2000.

21. Abbott SL, Cheung WK, Janda JM. The genus Aeromonas: biochemical characteristics, atypical reactions, and phenotypic identification schemes. JClin Microbiol. 2003;41(6):2348-57.

22. Qaralleh HN, Abboud MM, Khleifat KM, Tarawneh KA, Althunibat OY. Antibacterial activity in vitro of Thymus capitatus from Jordan. PakJ Pharm Sci. 2009;22(3):247-51.

23. Citarasu T, Dhas A, Velmurugan K, Thanga V, Kumaran V. Isolation Of Aeromonas Hydrophila From Infected Ornamental Fish Hatchery During Massive Disease Outbreak. Int J Res. 2011;2(1):3741.

24. Belém-Costa A, Cyrino JEP. Antibiotic resistence of Aeromonas hydrophila isolated from Piaractus mesopotamicus (Holmberg, 1887) and Oreochromis niloticus (Linnaeus, 1758). Sci. agric 2006;63(3).

25. Lukkana M, Wongtavatchai J, Chuanchuen R. Class 1 integrons in Aeromonas hydrophila isolates from farmed Nile tilapia (Oreochromis nilotica). JVet Med Sci. 2012;74(4):435-40.

26. Shak JR, Whitaker JA, Ribner BS, Burd EM. Aminoglycoside-resistant Aeromonas hydrophila as part of a polymicrobial infection following a traumatic fall into freshwater. J Clin Microbiol. 2011;49(3):1169-70.

27. Fabio A, Corona A, Forte E, Quaglio P. Inhibitory activity of spices and essential oils on psychrotrophic bacteria. New Microbiol. 2003;26(1):115-20.

28. Moreno S, Scheyer T, Romano CS, Vojnov AA. Antioxidant and antimicrobial activities of rosemary extracts linked to their polyphenol composition. Free Radic Res. 2006;40(2):223-31.

29. Gonzalez MJ, Marioli JM. Antibacterial activity of water extracts and essential oils of various aromatic plants against Paenibacillus larvae, the causative agent of American Foulbrood. J Invertebr Pathol. 2010;104(3):209-13.

30. Rota MC, Herrera A, Martínez RM, Sotomayor JA, Jordán MJ. Antimicrobial activity and chemical composition of Thymus vul garis, Thymus zygis and Thymus hyemalis essential oils. Food Control. 2008;19(7):681-7.

31. Reynolds JEF. Martindale the extra pharmacopoeia.London: Royal Pharmaceutical Society of Great Britain; 1996.

32. Bajpai VK, Rahman A, Kang SC. Chemical composition and in hibitory parameters of essential oil and extracts of Nandina domestica Thunb. to control food-borne pathogenic and spoilage bacteria. Int J Food Microbiol. 2008;125(2):117-22.

33. Amensour M, Bouhdid S, Fernández-López J, Idaomar M, Senhaji NS, Abrini J. Antibacterial Activity of Extracts ofMyrtus communisAgainst Food-Borne Pathogenic and Spoilage Bacteria. Int Food. 2010;13(6):1215-24.

34. Senatore F, Napolitano F, Apostolides Arnold N, Bruno M, Herz W. Composition and antimicrobial activity of the essential oil ofAchillea falcata L. (Asteraceae). Flavour Frag J. 2005;20(3):291-4.

35. Khder AK. Effect of Allium sativum and Myrtus communis on the elimination of antibiotic resistance and swarming of Proteus mirabilis. Jordan J Biol Sci. 2008;1(3):124-8.

36. Alishahi M, Ghorbanpoor M, Najafzadeh H, Pashmforoosh M. An- 


\section{Al Laham SA et al.}

tibacterial Effects of Some Medical Plant Extracts On Aeromonas Hydrophila, Yersinia Ruckeri And Streptococcus Iniae. Sci Res Iranian Vet J. 2010;2(27):21-30.

37. Caturla N, Perez-Fons L, Estepa A, Micol V. Differential effects of oleuropein, a biophenol from Olea europaea, on anionic and zwiterionic phospholipid model membranes. Chem Phys Lipids. 2005;137(1-2):2-17.

38. Omar SH. Oleuropein in olive and its pharmacological effects. Sci Pharm. 2010;78(2):133-54. 